\title{
Policies and Practices for Supporting Successful Knowledge Transfer from Public Research to Firms
}

ANTHONY ARUNDEL

\subsection{Introduction}

In the last decades, governments in many countries have added a third goal of community engagement to the university goals of teaching and research. Although there are many types of engagement, a primary focus is to encourage universities to support the commercialization of university-produced knowledge by private sector firms, with the expectation that this will improve competitiveness, living standards, and employment. This also requires universities to adopt some of the goals of public research institutes such as the Fraunhofer Institutes in Germany, which were established to fulfill this role. The combination of universities and publicly funded research institutes are referred to in this chapter as "public research" or "public research organizations."

Multiple types of policy and practice are involved in successful knowledge transfer and commercialization. Successful transfer results in products or processes, derived in part on discoveries or inventions made by researchers in the public research sector, that are either introduced onto the market and acquired by users or implemented in the business processes or functions of firms or government organizations. Successful transfer is difficult to identify (see Chapter 12) and consequently many pre-commercial metrics are used as a proxy, such as the licensing of public research inventions or the establishment of startups.

The discussion of policies and practices in this chapter draws on the published literature and six national case studies, three of which are for high-income countries (Germany, the Republic of Korea, and the United Kingdom) and three from middle-income countries (Brazil, China, and 
South Africa). These six countries show a range of policies and practices for knowledge transfer and a variety of contextual conditions that influence success, including different industrial structures and levels of technological competence within the public research sector and the business sector. In the last few decades, all six countries have undergone major changes in national policies with the goal of improving rates of knowledge transfer and commercialization.

Section 10.2 evaluates the context for successful knowledge transfer and commercialization, exploring the effects of linear and nonlinear models of innovation and how these models influence our understanding of the demand-side requirements for knowledge transfer. Section 10.3 draws on the literature and the case studies to identify "what works" and uses the case studies to illuminate the contextual factors that influence outcomes. Section 10.4 provides brief descriptions of changes in knowledge transfer policy practices in each of the six case countries and an evaluation of the causes of the changes. Section 10.5 draws conclusions and recommendations for supporting knowledge transfer.

\subsection{Models of Knowledge Transfer}

Knowledge transfer can occur via multiple channels, as discussed in Chapter 2. Different methods for knowledge transfer can result in equally successful results, indicating equifinality, in which multiple causal paths can lead to the same desired outcome (Ordanini et al., 2014). The probability of a successful outcome is affected by many contextual factors that are not the direct target of knowledge transfer practices, such as the national industrial structure, the firm's main sector of activity, the national or regional level of economic development, the type of research conducted by public research organizations, and the technological and innovation capabilities of both the public research sector and private sector firms.

The type of research varies by the domain or field of science, but also between basic and applied research. Basic research is expected to have long time lags between discovery and commercialization, whereas applied research is closer to the market and therefore has shorter time lags. The widely disparaged but still powerful "linear model" of innovation assumes that basic research, conducted by universities and some public research institutes, is followed by applied research, either by public research organizations or firms, that results in commercial products and processes. The linear model, or the "mode 1" conception of knowledge 
transfer (Gibbons et al. 1994), underpins the American Bayh-Dole Act of 1980.

The linear model has two assumptions. First, it views knowledge flows as unidirectional, flowing from public research organizations to firms. Second, it assumes that there is an ample supply of firms that are capable of taking university discoveries and further developing them into commercial products and processes, but unwilling to invest in further research because of a lack of patent protection on inventions. The BayhDole Act permits universities to provide the necessary patent protection.

The assumption of an ample supply of firms with the absorptive capacity to develop university inventions into products and processes probably reaches its closest approximation to reality in the United States of America (U.S.), where there is a larger pool of firms that are close to the technological frontier than in many other countries. Firms in sciencebased industries are also more likely to successfully use university inventions within a mode 1 linear model because they have the necessary capabilities to work within this model. However, this model does not hold in many countries and is also unlikely to be true in some regions of the U.S., in sectors where innovation is not based on science, or among specific types of firm, such as SMEs that lack advanced technological or scientific capabilities.

The mode 1 linear model of innovation assumes that there is always sufficient demand from national firms that are capable of using knowledge produced by universities. This has led to national policy reports in almost every developed country lamenting that excellent research results produced by national universities fail to be picked up and developed by national firms, with the blame placed on the universities or on the lack of programs to transfer knowledge from universities to capable firms. An example is a South African White Paper that states:

Whilst South Africa has many examples of good R\&D work, it has only managed to commercialise and exploit the research results in a few instances. Part of the problem is undoubtedly the absence of mechanisms to ensure that industry benefits maximally from the [output of public research] and other basic and/or applied research performers. (cited in Kahn 2017: 12).

The "mode 2" model (Gibbons et al. 1994) revises the original linear model based on technology push by introducing the need for universities to conduct applied research and consequently provide firms with inventions that are closer to the market. Market proximity has been measured 
through "technology readiness levels" or "proof of concept" (Heder 2017; Munari et al. 2017). Yet the mode 2 model is still insufficient because it fails to integrate the other half of the knowledge transfer process: the absorptive capacity of firms. Caryannis and Campbell (2009) and Miller et al. (2016) extend the mode 2 model by recognizing the need for demand pull from firms to the public research system, such that public research scientists are aware of industry needs and are able to act on this knowledge by altering their research programs. In the South African case, Kaplan (2008) argues that this occurs infrequently because there are few incentives for researchers to change or adjust their research programs to meet domestic needs. Furthermore, government officials in South Africa have understood a failure to transfer knowledge as a network failure, where there is a lack of bilateral communication between university academics and the managers of firms, or as a financial problem, with insufficient early-stage funding for startups or incentives for university researchers, instead of a possible "mismatch between demand and supply" (Kahn 2017: 28).

This is not only a problem for South Africa - in many countries, academics are comfortable within a technology-push model because it requires less involvement and provides more independence, permitting academics to conduct the type of research that they want to do and in the way they want to do it. This model does not require academics to conduct research that meets the needs of industry. This goes deeper than arguments over the "different cultures" of academics and firms, which often revolve around deadlines and confidentiality and arise when academics are involved in a collaborative research project with industry. The greater issue is the willingness of public researchers to engage with industry in the first place. O'Shea et al. (2008) note that there are large differences among academic researchers in their interest in engaging with a variety of stakeholders, while Arque-Castells et al. (2016) find that approximately one-third of Spanish and Portuguese academics that hold a patent for an invention are not interested in working with firms, even with financial incentives from a possible share of future royalty income.

The "mode 3" model for knowledge transfer assumes that effective transfer requires a pool of firms with sufficient absorptive capabilities (Hallam et al., 2014) and that there is a reverse knowledge flow whereby firms provide public research scientists with information on their needs and that this information influences the research projects of public research scientists. Miller et al. (2016) argue that this "demand pull" is the dominant factor in the process of effective knowledge transfer. It is 
likely to be of critical importance to collaborative research between the public research sector and firms. Mode 3 therefore follows a nonlinear model that is aligned with theories of national innovation systems (Lundvall 1992; Hallam et al. 2014).

In many countries, an awareness of demand pull has existed for decades and was met through public research institutes that conducted applied research for local industries, but universities were often outside this system. An example is Germany, which maintains a clearly defined basic research infrastructure, including universities, the Max Planck Institutes, and, to a certain extent, the Helmholtz Institute. Researchers at Max Planck do not see knowledge transfer as part of their role and have been largely unaffected by the trend, in many countries, to introduce third-pillar "community engagement" into public research organizations (see Chapter 5). Conversely, other public research institutes such as the Fraunhofer Institutes and the Leibnitz Institute view knowledge transfer as an important part of their role.

Out of the six country case studies, the United Kingdom has probably experimented the most with policies to encourage demand pull. Since the early 2000s, UK policy identified the disadvantages of too much focus on IP as part of a technology-push model and encouraged universities to become active players within a complex ecosystem of innovation characterized by collaboration and knowledge exchange (see Chapter 4). This was supported by financial incentives that allocated 9 percent of total government research funding on the basis of the income universities obtained from knowledge transfer activities, along with research subsidies to firms to participate in collaborative research with universities.

A "mode 3" model based on an understanding of national innovation systems recognizes the roles of both technology push and demand pull, with a focus on both public research and the capabilities and needs of national firms. Both public science and the private sector play strong roles, such that the failure to transfer knowledge could be due to a range of deficiencies on each side. Furthermore, mode 3 includes knowledge transfer intermediaries, such as university "technology transfer" and "knowledge transfer" offices, that play a greater role than simply preparing patent applications and licensing contracts. Instead, effective knowledge intermediaries need to actively find firms that could benefit from public research and encourage informal and formal contacts and collaborations between public research scientists and firms (Garengo 2019).

The terminology for knowledge intermediaries reflects the different conceptions of how knowledge flows. The original concept of 
a "technology transfer" office is based on the linear model, whereby knowledge flows in one direction from public research to firms. The update to "knowledge transfer" offices remains within this paradigm, with the exception that "knowledge" includes nontechnical knowledge such as works protected by copyright. The most recent term, although still rarely used for practical purposes, is "knowledge exchange," which views the process as involving a bidirectional flow of knowledge. This also includes cocreation as part of "open innovation" (Chesbrough 2003; Miller et al. 2016), where researchers from firms and public research organizations jointly develop inventions, often through collaborative research projects.

\subsubsection{The Knowledge Capabilities Gap}

While the linear model assumes that there is a pool of capable firms that can make use of results flowing out of a "public research pipeline," mode 3 models assume that a pool of capable firms may not exist: national firms might lack the absorptive capacity to use the outputs of the public research sector. This can be captured through the concept of a knowledge (or technological) capability gap between firms and public research.

The effect of a knowledge capability gap has been identified in several contexts. Haas et al. (2015), in an analysis of 952 problems posted on an online forum, find that knowledge providers are more likely to allocate time to solving a posted problem if the problem matches their expertise. In addition, they find an inverse " $U$ " relationship between the novelty of a problem and the probability that solution providers will respond. Chan et al. (2018) examine the adoption of novel ideas obtained from a firm's customers through crowdsourcing and find that the adoption of the idea by the firm declines with the novelty of the idea, as measured through newness, distinctiveness, and originality. Criscuolo et al. (2017) also find an inverse "U" relationship between the novelty of 556 research proposals for R\&D funding and the share of requested funding received.

A study by Kotha et al. (2013) provides an empirical example of the effect of a knowledge gap on the licensing of invention disclosures from an unidentified American university between 2001 and 2006. Out of 3,776 invention disclosures, 874 inventions were patented, of which 38 percent (339) were licensed, while 14 percent (416) of the nonpatented inventions were also licensed, giving a total of 755 licensed inventions. Of note, more licenses were given to non-patented inventions 
than to patented inventions. The authors calculate the scientific "distance" or technological complexity of each invention disclosure, measured by the number of knowledge domains used for the invention and the prevalence of cross-disciplinary research between the domains. Inventions with low technological complexity are likely to provide minor increments to existing knowledge, while very technologically complex inventions are likely to represent major inventions. The authors use survival analysis to determine the probability of each invention being licensed. Similar to Criscuolo et al. (2017) and Chan et al. (2018), Kotha et al. (2013) find an inverse " $U$ "-shaped relationship between the probability of licensing and scientific distance. Inventions of medium complexity are more likely to be licensed than inventions of both low and high complexity. This effect is mediated by the inventor team's experience with licensing. Greater experience increases the probability of licensing all types of invention, while low experience decreases the probability of licensing more technologically complex inventions.

The implication of this research is that a large gap between the technological complexity or novelty of an invention or idea and the capabilities of potential users decreases the probability that an invention or idea will be taken up, probably because potential users lack the absorptive capacity to understand and adapt an invention or idea for their own uses. Conversely, inventions or ideas with low complexity or novelty are also less likely to be taken up, possibly because firms are capable of developing similar solutions. In the Kotha et al. study, university inventions with low complexity may be less likely to be licensed because firms can work around the patent, saving the cost of taking out a license. The positive effect of the previous licensing experience of the inventors could increase the probability of licensing complex inventions because it signals to firms that the inventors are willing to assist firms in understanding and further developing complex inventions into commercially useful products or processes.

The gap in capabilities between university inventors and a firm is likely to vary between countries. For instance, the average absorptive capacity of the potential pool of licensees in a technologically leading economy such as the U.S. is likely to be greater than in a middle-income economy such as Brazil. In addition, inventions by universities in middle-income economies are also likely to be less novel or complex than they are in the U.S. Nevertheless, the literature suggests that what matters is the gap in technological capabilities between university academics and domestic firms, rather than the absolute level of complexity of the 
university invention. The gap needs to be sufficiently large to provide inventions that firms could not develop themselves, but not so large that firms are unable to understand and commercialize them. Of course, there may be islands of competence where the technological gap between public research and firms is within a "sweet spot" for licensing, as shown by the high technological capabilities and close linkages with public research of aircraft manufacturers in Brazil (De Negri and Rauen 2017) or petrochemical firms such as Sasol in South Africa (Kahn 2017).

The technological gap can also occur in the other direction, with universities operating at a lower level of technological competence than firms. In this case, firms have little interest in licensing inventions from universities. One example is large firms in the Republic of Korea, which benefited from public research from the 1970s until the 1990s. However, after the late 1990s, the capabilities of large firms in the Republic of Korea exceeded the capabilities of the public research sector (see Chapter 6), with one consequence being a shift in policy to encourage public research institutions to support technologically lagging SMEs.

The concept of a knowledge gap applies not only to licensing IP, but also to involvement in collaborative research. When the knowledge is gap is high, firms might resort instead to contracting out research to public research organizations.

Out of the six country case studies, four identify barriers to knowledge transfer as a result of a knowledge gap where the capacities of universities exceed those of firms (Brazil, China, South Africa, and the United Kingdom), and the Republic of Korea identifies a knowledge gap where the capacities of firms gradually exceeded those of universities. Germany is the only case study where a knowledge gap does not appear to be a significant issue, either because of the well-developed infrastructure of public research institutes that serves the requirement for applied research by German firms, or because of a lack of comprehensive data for Germany on knowledge transfer channels other than those based on patents (see Chapter 5).

The technological gap between universities and firms can be imagined as a situation where knowledge must be "pumped uphill" to overcome the deficit in the absorptive capacities of firms. The "pump" can consist of demand-side activities such as investments by firms in absorptive capacity, the active assistance of academics in helping firms to understand their inventions, or closer collaboration between firms and academics so that the last are more knowledgeable about the problems that firms face. 
Policy can contribute to the pump by subsidizing the R\&D activities of firms, providing subsidies for collaborative research between firms and universities, or supporting university practices that encourage inventors to assist firms, for instance, by taking up short-term contracts with firms to assist with knowledge transfer.

\subsection{Appropriate Policies and Practices}

Successful knowledge transfer from public research depends on context: the technological and related capabilities of firms and public research organizations, the gap between these capabilities, and the industrial structure of a country, among other factors.

From the perspective of the mode 3 model, there are three main actors in knowledge transfer: the public research organization (a university or public research institute), intermediaries, particularly knowledge transfer offices, and firms. Figure 10.1 charts the relationships between these three nodes and identifies the main factors for each actor that can influence successful knowledge transfer.

The set of factors that promote knowledge transfer are likely to differ depending on the knowledge transfer channel (startups, contract research, collaboration, or IP licensing), interactions between policies, and interactions with other knowledge transfer channels. The systems perspective underlying the mode 3 model of knowledge transfer emphasizes the need for policies and practices to bridge the knowledge gap
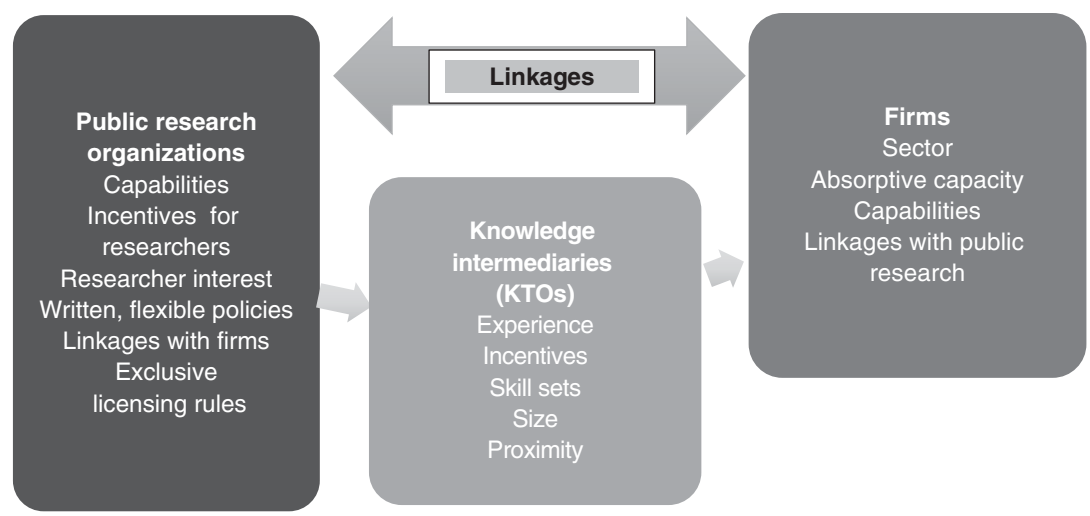

Figure 10.1 Factors that influence knowledge transfer Source: Authors 
between public research and firms and to support knowledge exchange in addition to knowledge flows from academia to firms.

The question for policy is which factors need to be further developed and which factors are functioning adequately? Table 10.1 provides a basic framework for answering this question, based on the concept of a knowledge gap between public research and firms. Table 10.1 should be interpreted in respect to specific knowledge domains, for instance it could refer to knowledge on food manufacturing (safety, shelf life, processing, packaging, etc.) or to pharmaceutical manufacturing.

Successful knowledge flows require motivating all three partners (researchers, KTO intermediaries, and firms) to participate in knowledge

Table 10.1 Policies to support knowledge transfer for differing capabilities of public research organizations and firms

\begin{tabular}{|c|c|c|c|}
\hline & & \multicolumn{2}{|c|}{ Level of firm capabilities } \\
\hline & & High & Low \\
\hline \multirow[t]{2}{*}{$\begin{array}{l}\text { Level of public } \\
\text { research } \\
\text { capabilities }\end{array}$} & High & $\begin{array}{l}\text { A Ensure } \\
\text { knowledge } \\
\text { flows through } \\
\text { flexible } \\
\text { licensing and } \\
\text { contracting } \\
\text { rules; incentives } \\
\text { for public } \\
\text { research } \\
\text { scientists to } \\
\text { disclose } \\
\text { inventions and } \\
\text { assist firms }\end{array}$ & $\begin{array}{l}\text { B Bridge the gap } \\
\text { through polices } \\
\text { to build firm } \\
\text { capabilities and } \\
\text { incentives for } \\
\text { the public } \\
\text { research sector } \\
\text { to interact with } \\
\text { firms }\end{array}$ \\
\hline & Low & $\begin{array}{l}\text { C Bridge the gap } \\
\text { through } \\
\text { policies to build } \\
\text { public research } \\
\text { capabilities and } \\
\text { incentives for } \\
\text { firms to interact } \\
\text { with the public } \\
\text { research sector }\end{array}$ & $\begin{array}{l}\text { D Improve public } \\
\text { research } \\
\text { capabilities } \\
\text { (supply), firm } \\
\text { capabilities } \\
\text { (demand), and } \\
\text { knowledge } \\
\text { exchange } \\
\text { between them }\end{array}$ \\
\hline
\end{tabular}

Source: Authors 
transfer. In cell A of Table 10.1, where the capabilities of both public research and firms are high (and with a suitable knowledge gap somewhere near the top of the inverse " $U$ " distribution), the role of policy is to ensure that there are appropriate incentives for interactions and capabilities in place for the three main actors in knowledge transfer. For cells B, C, and D, additional policies to either build supply capabilities in the public research sector or demand capabilities in firms are likely to be required in addition to the policies identified in cell A. For example, when public research capabilities are high but firm capabilities are low (cell B), incentives are required to encourage public research academics to interact with firms, in addition to $\mathrm{R} \& \mathrm{D}$ or other types of subsidy to build firm capabilities. Cell C provides the opposite case where firm capabilities are high but public research capabilities are low. Here, incentives could be required to encourage firms to interact with the public research sector, in addition to supply-side policies to improve the capabilities of public research academics.

Policies and practices can be usefully divided into two groups: those that directly address knowledge transfer, such as incentives, funding for KTOs, etc., and those that affect contextual factors such as the technical capabilities of firms or the industrial structure. Most of the existing literature on policies and practices to support knowledge transfer is relevant to cell A in Table 10.1 and concerns direct methods to improve knowledge transfer. Nevertheless, this literature is of use to all other conditions because it identifies practices that support interactions between public research and firms. These direct policies and practices are discussed below for each of the three main actors: public research organizations, knowledge intermediaries, and firms.

\subsubsection{Policies, Practices, and Characteristics of Public Research Organizations}

A history of previous linkages between a public research organization and firms increases the interest of researchers in knowledge transfer activities and consequently the probability of knowledge transfer (D'Este and Patel 2007; Libaers 2012; Padilla-Meléndez and GarridoMoreno 2012; Grimpe and Hussinger 2013; Agiar-Diaz et al. 2016). In addition, academics can be motivated to collaborate with firms by previous involvement in applied research and the importance of applied research to career advancement (Abreu and Grinevich 2013; Abreu et al. 2016; Zhang et al. 2016). In contrast, practices such as a requirement to disclose inventions with commercial potential have 
only a small effect on the involvement of academics in knowledge transfer (Abreu et al. 2016).

Combining informal and formal knowledge transfer channels can have a positive effect on the innovation activities of firms (Siegel et al. 2003; Grimpe and Hussinger 2013). Informal channels build up relationships and trust between academic researchers and firms that can lead, over time, to research relationships that produce IP (Weckowska 2015). The use of both informal and formal channels could be especially important to spinoffs (Hayer 2016).

Another type of linkage is when public research organizations and firms coinvent through a collaborative research agreement. This can result in corporate patents that include university inventors as a contributor through formal or informal channels. Walsh (2016) reports that 4 percent of corporate triad patents held by American firms between 2001 and 2004 included formal or informal input from universities.

An important factor for encouraging knowledge transfer via IP-mediated methods is financial incentives for academic staff to disclose inventions and participate in the knowledge transfer process (Walter et al. 2013). The size of the financial reward has a positive effect, either through a one-off lump sum or a share of ongoing royalties (Friedman and Silberman 2003; Siegel et al. 2003; Lach and Schankerman 2004; Debackere and Veugelers 2005; Walter et al. 2013), although in Brazil an increase in status and recognition has also been a driver for increased academic interest in knowledge transfer activities (Closs et al. 2013).

Studies of academics find that their interest in participating in knowledge transfer can also be increased by including knowledge transfer activities in performance measures (Siegel et al. 2003; Closs et al. 2013; Ranga et al. 2016) and permitting academics to take time off to work with a firm.

Barriers to researcher interest in knowledge transfer include personal characteristics that create a lack of interest in knowledge transfer or in financial incentives, teaching and other responsibilities that reduce the time available for academics to engage in knowledge transfer (Closs et al. 2013), concern over delays in publishing knowledge linked to IP, a lack of financial support (for instance, when the academic must cover the patenting costs, which can be an issue in middle-income countries), a lack of research ideas with commercial potential, limited experience with interactions with firms (D'Este and Patel 2007), and differences between academic and business cultures, although this may be less important than commonly believed. In a UK survey of both businesses and academics, less than 7 percent of both groups cited cultural differences as an important barrier 
to interactions. In comparison, the most commonly cited barrier was "insufficient internal resources," cited by 42 percent of businesses and 28 percent of academics (Hughes and Kitson 2012).

Bureaucratic and inflexible rules for knowledge transfer activities can act as a barrier to the participation of both academics and firms in knowledge transfer (Muscio et al. 2016). Knowledge transfer via licensing is supported by clear IP regulations that provide guidance to staff (Baldini et al. 2006) and a flexible approach on the part of the public research organization to licensing (Lerner 2005; Okamuro and Nishimura 2013; Barjak et al. 2015; Shen 2016).

Policies that contribute to knowledge transfer via the establishment of startups include dedicated programs (support for developing business plans, etc.) and facilities (such as an incubator) (Berbegal-Mirabent et al. 2015; Muscio et al. 2016) and employment conditions that permit academics to take leave to work with startups. High licensing income for inventors has been found to reduce the number of startups, possibly because it provides a less demanding source of income (Markman et al. 2004; Barjak et al. 2015). However, a European study that evaluated the effect of multiple policies on the establishment of startups found that the share of license income retained by inventors had a positive effect on the number of startups (Barjak et al. 2015).

\subsubsection{Policies, Practices, and Characteristics of KTOs}

The experience of the KTO, often estimated by the number of years that the KTO has been active, has a significant positive effect on many knowledge transfer outcomes (Friedman and Silberman 2003; Conti and Gaule 2011; WIPO 2011; Berbegal-Mirabent and Sabate 2015). The effect is due to a positive relationship between KTO age and institutional experience with knowledge transfer activities.

To be effective at knowledge transfer tasks, KTOs require highly skilled staff. Relatively low salaries, as noted in the case studies for Brazil and the Republic of Korea, can result in a failure to attract skilled employees. In addition, policies that do not permit KTOs to retain a percentage of license revenues can limit the ability of KTOs to offer benefits to staff.

Several of the case study countries provide regional or national KTOs or technology exchanges that can serve multiple public research organizations (China, Brazil, Germany). However, the preference of larger public research organizations is to retain their own KTO instead of using the services of a regional KTO. This suggests that proximity 
between a KTO and its institution is a strong advantage (see Chapter 4). This could be due to the ability of proximate KTOs to develop close working relationships with researchers and local firms.

\subsubsection{Policies, Practices, and Characteristics of Firms}

Two consistent results from the literature are that firms dislike rigid rules over IP and firm involvement in knowledge transfer from public research organizations increases with the firm's R\&D intensity (an indicator of technological capabilities) (Okamuro and Nishimura 2013; Maria et al. 2014; Kafouros et al. 2015). Okamuro and Nishimura (2013) also find that firm involvement with universities increases with the number of universities in a region, possibly because it improves the probability of a good match between the needs of firms and what universities can offer, or because greater competition between universities increases the flexibility of academic and KTO staff.

A major policy challenge is to create demand pull from firms, which requires firms with sufficient absorptive capacity to take an interest in public research inventions. Demand pull can be created through subsidies for R\&D and innovation activities within firms, subsidies to permit firms to hire trained graduates from public research organizations and to thereby interact with these institutes, such as the THRIPS program in South Africa, or subsidies for consulting, contract research, or collaboration with universities or public research institutes.

A second issue related to demand is ensuring that firms are aware of research projects and inventions developed in the public research sector. Several countries have established national technology exchanges for this purpose (e.g., China and Brazil), but the effectiveness of these exchanges appears to be limited. This could be because firms have many other methods of identifying interesting projects or capabilities, such as reading the scientific literature or searching patent databases. Alternatively, KTOs can publish relevant information that is oriented to the needs of local firms. Due to the importance of proximity in firm-university contacts, this could be an important complement to other sources of information used by firms.

\subsubsection{National versus Institutional Policies and Practices}

Knowledge transfer programs can be supported at the national level and at the institutional level. Munari et al. (2016), in an analysis of European 
programs at 125 KTOs to fund the gap between invention and the development of a commercially viable prototype, report a shift over time in national centralized programs to decentralized activities at the level of the institution or region, which then shifts back again to a centralized program. The authors suggest that centralization is high at the start of policies to initiate and encourage knowledge transfer activities, which are then replaced by local experimentation that builds on in-depth knowledge of the needs of local firms. Over time this is then replaced by further centralization to "refine and complement local initiatives with measures promoting critical mass and selectivity."

A similar pattern appears to have occurred in the United Kingdom (see Chapter 4). The 2009 UK survey of university academics found that academics in regional areas were more intensively involved in university-industry linkages than academics in the metropolitan regions and that teaching-oriented universities were also very active in these linkages (Zhang et al. 2016). However, a policy of using knowledge transfer for local economic development (supported by regional development authorities) was abandoned in 2010. This was followed by a shift to finding the highest bidder for university IP, no matter where located.

In many countries there is an unavoidable tension between a national goal to maximize income from IP and goals to use knowledge transfer to improve the competitiveness of domestic or regional firms (Kassicieh 2012; Rosli and Rossi. 2014). Until recently, the Republic of Korea explicitly followed a policy of encouraging universities to support the local economic development of SMEs, at the cost of reduced IP income (Lee and Shin 2017). SMART specialization platforms can help to overcome these problems by focusing on promoting regional strengths and providing mechanisms whereby firms can influence public sector research through demand pull. This can require an open knowledge exchange environment to assist in building effective relationships and for KTOs to actively support cocreation (Miller et al. 2016).

\subsection{Policies and Practices for Knowledge Transfer: Case Study Results}

Several of the case studies identify a common pattern: direct policies to support knowledge transfer were implemented to address one of the players in the knowledge transfer system without sufficient steps to ensure that all players could participate, including a failure to adequately address 
a knowledge gap between public research and firms. As a result, direct policies that increased the output of patented inventions in Brazil, the Republic of Korea, China, and South Africa were not matched by an equivalent increase in patent licensing. Over time, the mix of policies and practices were changed to address inadequacies in existing policies (China, Brazil, South Africa, and the United Kingdom), changing circumstances (Republic of Korea) and changes in political goals (United Kingdom).

\subsubsection{Brazil (Chapter 7)}

The Innovation Act of 2004 addressed the knowledge gap, a lack of incentives for public researchers to work with firms, and the need for knowledge intermediaries. It allowed the government to provide grants to firms to invest in innovation (thereby building capabilities) and created a framework for university-firm interactions, including the right for universities to sign exclusive licensing agreements with firms and provide staff with financial compensation. The Act also required all universities and public research organizations to have a KTO or use the services of a shared KTO. The Act appears to have increased university patenting. Between 2000 and 2012, Brazilian universities increased their share of total patents tenfold, from 0.38 percent to 3 percent. However, the Act had several flaws: it failed to provide sufficient funding to KTOs, required KTO staff to be public servants, and did not specify the specific mechanisms by which researchers could receive a share of license income for their patents. In 2016 the Act was replaced by a new Act that addressed many of the shortcomings of the 2004 Act, but it did not resolve the issue of financial incentives for university researchers.

\subsubsection{Republic of Korea (Chapter 6)}

The Government of the Republic of Korea established public research institutes in 1973. Since then, public research institutes have played a greater role than universities in public $\mathrm{R} \& \mathrm{D}$ and knowledge transfer. In the late 1990s, policies were introduced to improve the role of universities in knowledge transfer, culminating in the Technology Promotion Act of 2000, which required universities to have KTOs and shifted ownership of IP from the government or individual professors to KTOs. The number of KTOs increased from seventeen in 2003 to 263 by the mid-2010s. This generated a large increase in university patents, but little additional commercialization. The government has also tried to 
engineer a shift in the role of universities and public research institutes from supporting large firms to supporting knowledge transfer to SMEs. Large firms no longer required public research support because their own internal capabilities exceeded those of public research institutes.

The shift in the role of public research institutes to support SMEs and regional economic development has not succeeded due to the funding model for salaries of researchers. Financing is linked to the number of projects, which compels researchers to conduct many projects within a short period of time. The result is that projects are completed before a discovery reaches a level of development that is appropriate for SMEs. Given a large knowledge gap between public research institutes and SMEs, there is a need to make sure that new technologies are developed to the level of demonstrated prototypes in operational environments (technology readiness level 7).

In the late 2000s, the government made several further changes to the knowledge transfer system, by providing funding for universities to revitalize regional economies and by relaxing restrictions on exclusive licensing and permitting universities to license to foreign firms. KTOs were also instructed to obtain more information on the needs of firms in order to create demand pull. The government also increased the rate of funding for KTOs from 1.3 percent of research expenditures in 2010 to 3.3 percent in 2015, with the expectation of improving the skills and quality of KTO staff. To date there is little evidence that the policy revisions have paid off in an increase in commercialization via licensing. The share of total license income out of total R\&D expenditures for public research institutes and universities combined was 1.38 percent in 2009 and 1.35 percent in 2014 .

The example of the Republic of Korea suggests that government policy has lagged behind the needs of industry (public research institutes failed to maintain an optimal knowledge gap with both large firms and SMEs). Policy also appears to have dropped the focus on domestic industry in favor of increasing the amount of license income earned by public research institutes. This is an imperfect measure of successful knowledge transfer in a country where most licenses are based on lump sum payments instead of running royalties on the actual sales of products based on licensed inventions.

\subsubsection{China (Chapter 8)}

The patenting activity of Chinese public research organizations has increased substantially, but both patent applications and licensing are 
concentrated in a small number of research universities. The main barrier to licensing is low demand from domestic firms, suggesting a continuing knowledge capability gap. Half of licenses go to foreign-owned firms.

To address these issues, the 1996 law on knowledge transfer for universities and public research institutes was amended in 2015 to support the knowledge transfer capabilities of public research organizations and the technological capabilities of firms. Before 2015 the transfer of university IP had to obtain the approval of the Ministry of Finance, and income from knowledge transfer also went to the Ministry of Finance. The 2015 amendment gave full control of IP and related income to universities and public research institutes and allowed these organizations to give much larger financial incentives to researchers and KTO personnel. Other Chinese policies supported demand pull by involving firms in research cooperation with universities. Firms participate in 90 percent of national R\&D projects and lead approximately half of science and technology projects.

\subsubsection{South Africa (Chapter 9)}

South Africa has world-class universities that focus on leading-edge research. A substantial share of all research expenditures (24.5 percent) is for basic research as part of "Big Science." Research programs are primarily driven by academic interest. With the important exception of several industry-focused public research institutes that serve the petrochemical, pulp and paper, wine, and mining sectors and excellent linkages between university agricultural research and the agricultural sector, the South African research system is not designed to produce applied research of relevance to the majority of South African firms. A major challenge for knowledge transfer in South Africa is to improve the technological capabilities of South African firms outside of several sectors of excellence. Other challenges include shifting from a mode 1 to a mode 3 model for knowledge exchange on the part of public research organizations, for instance, by building closer relationships between firms and academics so that demand-pull influences are incorporated into research programs.

\subsubsection{United Kingdom (Chapter 4)}

The public research sector in the United Kingdom is dominated by universities, with 80 percent of research expenditures conducted by 
universities compared to a 20 percent share for public research institutes. Policies and practices for knowledge transfer in the United Kingdom have tracked academic research on how knowledge transfer occurs. Up until the early 2000s, practices followed the mode 1 model of a linear flow of knowledge from public research organizations to firms, with an emphasis on IP-mediated licensing. Currently, knowledge transfer is viewed as part of a "complex ecosystem of innovation characterized by collaboration and knowledge exchange among many actors" (Chapter 4). The importance of flexibility in negotiations between firms and universities is also recognized, with flexible policies on IP licensing, including the amount received by the inventor.

Policy for universities recognizes four types of knowledge transfer activities: commercialization (patenting, licensing, consulting, spinoffs), problem solving (collaborative research, contractual research, access to university facilities), people-based (conferences, invited lectures, enterprise education, etc.) and community-based (social enterprises, museums, public exhibits, open lectures, etc.). With the possible exception of community-based activities, all are relevant to the economic activities of firms. Universities vary in the depth of their activities in each of the four knowledge transfer activities, with teaching and regional universities more active in people-based and community-based activities and research-intensive universities more active in commercialization. This partly explains the high concentration of IP licensing. In fiscal year 2014-15, twenty-five universities produced 80 percent of university patent applications and twenty-seven universities earned 80 percent of contract income. In the late 2000s, IP income was approximately 3-4 percent of total income from all knowledge transfer activities.

KTO experience and learning over time has improved efficiency, with a decline in the number of patent applications since the mid-2000s to patents with a higher commercial potential. The quality of spinoffs has also improved, with an increase in the share that survive for three or more years. Demand-side policies include R\&D tax credits, Smart Programme grants to firms, the Small Business Research Initiative (SBRI) and support for venture capital.

\subsubsection{Germany (Chapter 5)}

Germany has a well-developed knowledge transfer system with clear delineations between public research institutes that specialize in basic research and public research institutes and universities of applied 
sciences that specialize in applied research of commercial interest to firms. Surveys of researchers from institutes that conduct applied research show that they give a high level of importance to knowledge transfer activities.

The German case emphasizes how knowledge transfer can form a functioning innovation system that can be difficult to change, due to the many actors and networks involved. Ownership of IP was changed in 2002 from the inventor to the inventor's institution to emulate the U.S. Bayh-Dole model. The switch was expected to increase the number of startups and patent applications by academics. Instead, up to 2008 the change in policy reduced the number of patents by university academics by 17 percent and had no effect on the number of startups (Czarnitzki and Licht 2017). These poor outcomes could be temporary effects that may dissipate after sufficient time to adjust to the new model. ${ }^{1}$

\subsection{Conclusions}

Over time, the conceptual model behind policies to support knowledge transfer has shifted from a mode 1 linear pipeline model to a mode 3 model that involves multiple actors in an innovation system, including different types of public research organization, knowledge intermediaries such as knowledge transfer offices, and private businesses. The mode 3 model recognizes the role of both supply-side activities on the part of public research and demand-side activities on the part of firms. A knowledge capability gap between public research and firms is required for public research results to be useful to firms, but too much of a gap will prevent firms from being able to acquire public research results, closing off demand. Current best practice recognizes that all actors in the system must have sufficient capabilities and incentives to participate in knowledge transfer activities including consulting, contractual research, collaborative research, and IP licensing.

Research finds that activities that create demand for knowledge produced by public research organizations, including both informal contacts and the participation of firms in contractual relationships with public research organizations, increases the probability of knowledge transfer and IP licensing. In addition, IP licensing can occur without any previous linkages

1 The inventor-owner model produced more spinoffs at Cambridge University, with a decline noted in spinoffs after Cambridge switched to university ownership of IP in 2005 (Chapter 4). 
between public research and firms. Nevertheless, knowledge transfer systems can benefit considerably from incorporating demand pull, for instance, by building close relationships between firms and research institutes to ensure that the needs of firms are included in applied research.

Best practice for public research organizations includes providing sufficient financial incentives and time for researchers to participate in knowledge transfer and to include knowledge transfer activities in career evaluations. Successful knowledge transfer can require researchers to expend considerable time on the process, from developing a patent application to working with firms or spinoffs to ensure follow-on development of an invention. KTOs need adequate financing to ensure that they develop sufficient expertise, the ability to hire and retain staff with a variety of necessary skills, incentives for successful transfer, and freedom to pursue a range of knowledge transfer activities, in addition to IP licensing. Firms must have the absorptive capacity to adapt and use knowledge and inventions to create product and process innovations. Best practice includes policy support for $R \& D$ and other innovationrelated activities and incentives for firms to work closely with public sector researchers for problem solving and commercialization.

A significant barrier to knowledge transfer in middle-income countries is the knowledge gap between the public research sector and firms. Overcoming this gap can require public research organizations to take inventions to the prototype stage or for public sector researchers to work closely with firms to assist follow-on development.

IP licensing is a minor but not unimportant part of knowledge exchange between public research and firms that facilitates knowledge transfer by protecting investments in follow-on research from imitation. It can also provide an additional funding stream for public research organizations, although this is likely to be a small share of total research expenditures. Best practice for IP licensing includes flexibility in drawing up IP contracts, negotiating skills on the part of KTO staff, and outreach activities to identify potential licensees. However, in many contexts, successful IP licensing is dependent on other good practices that support demand pull and research outputs that are relevant to the needs of firms.

\section{References}

Abreu, M., P. Demirel, V. Grinevich, and M. Karatas-Ozkan (2016). "Entrepreneurial practices in research-intensive and teaching led universities." Small Business Economics, 47: 695-717. 
Abreu, M. and V. Grinevich (2013). "The nature of academic entrepreneurship in the UK: Widening the focus on entrepreneurial activities." Research Policy, 42: 408-22.

Agiar-Díaz, I., N.L. Díaz-Díaz, J.L. Ballesteros-Rodríguez, and P. De Sáa-Pérez (2016). "University-industry relations and research group productions: Is there a bidirectional relationship?” Industrial and Corporate Change, 25: 611-32.

Arque-Castells, P., R.M. Cartaxo, J. Garcia-Quevdo, and M.M. Godinho (2016)."Royalty sharing, effort and invention in universities: Evidence from Portugal and Spain.” Research Policy, 45: 1858-72.

Baldini, N., R. Grimaldi, and M. Sobrero (2006). "Institutional changes and the commercialization of academic knowledge: A study of Italian universities' patenting activities between 1965 and 2002." Research Policy, 35: 518-32.

Barjak, F., N. Es-Sadki, and A. Arundel (2015). "The effectiveness of policies for formal knowledge transfer from European universities and public research institutes to firms." Research Evaluation, 24: 4-18.

Berbegal-Mirabent, J., D.E. Ribeiro-Soriano, and J.L.S. Garcia (2015). “Can a magic recipe foster university spin-off creation?” Journal of Business Research, 68: 2272-8.

Berbegal-Mirabent, J. and F. Sabate (2015). "Balancing basic and applied research outputs: A study of the trade-offs between publishing and patenting." Technology Analysis \& Strategic Management, 27: 1143-58.

Carayannis, E.G. and D.F.G. Campbell (2009). "'Mode 3' and 'Quadruple Helix': Toward a 21st-century fractal innovation ecosystem." International Journal of Technology Management, 46: 201-34.

Chan, K.W., S.Y. Li, and J.J. Zhu (2018). "Good to be novel? Understanding how idea feasibility affects idea adoption and decision making on crowdsourcing." Journal of Interactive Marketing, 43: 52-68.

Chesbrough, H. (2003). Open Innovation: The New Imperative for Creating and Profiting from Technology. Cambridge, MA: Harvard Business School Press.

Closs, L., G. Ferreira, V. Brasil, C. Sampaio, and M. Perin (2013). "What motivates Brazilian academic researchers to transfer technology?" Journal of Technology Management and Innovation, 8: 79-90.

Conti, A. and P. Gaule (2011). "Is the US out-performing Europe in university technology licensing? A new perspective on the European Paradox." Research Policy, 40: 123-35.

Criscuolo P., L. Dahlander, T. Grohsjean, and A. Salter (2017). "Evaluating novelty: The role of panels in the selection of R\&D projects." Academy of Management Journal, 60: 433-60.

Czarnitzki, D. and G. Licht (2107)., Leveraging Public Research for Innovation and Growth: Germany. WIPO project report.

De Negri, F. and C.V. Rauen (2017). Leveraging Public Research for Innovation and Growth: Brazil. WIPO project report. 
Debackere, K. and R. Veugelers (2005). "The role of academic technology transfer organizations in improving industry science links." Research Policy, 34: $21-342$.

D'Este, P. and P. Patel (2007). "University-industry linkages in the UK: What are the factors underlying the variety of interactions with industry?" Research Policy, 36: 1295-313.

Friedman, J. and J. Silberman (2003). "University technology transfer: Do incentives, management, and location matter?" Journal of Technology Transfer, 28: 17-30.

Garengo. P. (2019). "How bridging organisations manage technology transfer in SMEs and empirical investigation." Technology Analysis and Strategic Management, 31: $477-91$.

Gibbons, M., C. Limoges, H. Nowotny, S. Schwartzman, P. Scott, and M. Trow (1994). The New Production of Knowledge: The Dynamics of Science and Research in Contemporary Societies. London: Sage.

Grimpe, C. and K. Hussinger (2013). "Formal and informal knowledge and technology transfer from academia to industry: Complementarity effects and innovation performance." Industry and Innovation, 20: 683-700.

Haas, M.R., P. Criscuolo, and G. George (2015). "Which problems to solve? Online knowledge sharing and attention allocation in organizations." Academy of Management Journal, 58: 680-711.

Hallam, C., B. Wurth, and R. Mancha (2014). "University-industry technology transfer: A systems approach with policy implications." International Journal of Technology Transfer and Commercialisation, 13: 57-79.

Hayer, C.S. (2016). "A trajectory of early-stage spinoff success: The role of knowledge intermediaries within an entrepreneurial university ecosystem." Small Business Economics, 47: 633-56.

Heder, M. (2017). "From NASA to EU: The evolution of the TRL scale in public sector innovation." Innovation Journal: The Public Sector Innovation Journal, 22: article 3.

Hughes, A. and M. Kitson (2012). "Pathways to impact and the strategic role of universities: New evidence on the breadth and depth of university knowledge exchange in the UK and the factors constraining its development." Cambridge Journal of Economics, 36: 723-50.

Kafouros, M., C. Wang., P. Piperopoulos, and M. Zhang (2015). "Academic collaborations and firm innovation performance in China: The role of region-specific institutions." Research Policy, 44: 803-17.

Kahn M. (2017). Leveraging Public Research for Innovation and Growth: South Africa. WIPO project report.

Kaplan, D. (2008). "South Africa's national research and development strategy: A review." Science, Technology and Society, 9: 273-94.

Kassicieh, S. (2012). "The case for a difference public sector intellectual property policy." Proceedings of PICMET '12: Technology Management for Emerging Technologies, IEEE. 
Kotha, R., G. George, and K. Srikanth (2013). "Bridging the mutual knowledge gap: Coordination and the commercialization of university science." Academy of Management Journal, 52: 498-524.

Lach, S. and M. Schankerman (2004). "Royalty sharing and technology licensing in universities." Journal of the European Economic Association, 2: 252-64.

Lee, K. and H. Shin (2017). Commercializing Knowledge from the Public Sector in Korea: Current Situation and Future Challenges. WIPO project report.

Lerner, J. (2005). "The university and the start-up: Lessons from the past two decades." Journal of Technology Transfer, 30: 49-56.

Libaers, D. (2012). "Time allocation decisions of academic scientists and their impact on technology commercialization.” IEEE Transactions on Engineering Management, 59: 705-716.

Lundvall, B.A. (1992). National Systems of Innovation: Towards a Theory of Innovation and Interactive Learning. London: Pinter.

Maria, B.F.I., F. Rossi, and A. Geuna (2014). "Collaboration objectives and the location of the university partner: Evidence from the Piedmont region in Italy." Papers in Regional Science, 93: S203-S206.

Markman, G.D., P.T. Gianiodis, P.H. Phan, and D.B. Balkin (2004). "Entrepreneurship from the ivory tower: Do incentive systems matter?" Journal of Technology Transfer, 29: 353-64.

Miller, K., R. McAdam and M. McAdam (2016). "A systematic literature review of university technology transfer from a quadruple helix perspective: Toward a research agenda." R\&D Management, $48: 1-17$.

Munari F., E. Rasmussen, L. Toschi, and E. Villani (2016). "Determinants of the university technology transfer policy mix: A cross-national analysis of gap-funding instruments." Journal of Technology Transfer, 41:1377-405.

Munari, F., M. Sobrero, and L. Toschi (2017). "Financing technology transfer: Assessment of university-oriented proof-of-concept programmes.” Technology Analysis and Strategic Management, 29: 233-46.

Muscio, A., D. Quaglione, and L. Ramaciotti (2016). “The effects of university rules on spinoff creation: The case of academia in Italy." Research Policy, 45: 1386-96.

Okamuro, H. and J. Nishimura (2013). "Impact of university intellectual property policy on the performance of university-industry research collaboration." Journal of Technology Transfer, 38: 273-301.

Ordanini, A., A. Parasuraman, and G. Rubera (2014). "When the recipe is more important than the ingredients: A qualitative comparative analysis (QCA) of service innovation configurations." Journal of Service Research, 17: 134-49.

O'Shea, R.P., H. Chugh, and T.J. Allen (2008). "Determinants and consequences of university spinoff activity: A conceptual framework.” Journal of Technology Transfer, 33: 653-66. 
Padilla-Meléndez, A. and A. Garrido-Moreno (2012). "Open innovation in universities: What motivates researchers to engage in knowledge transfer exchanges?" International Journal of Entrepreneurial Behaviour \& Research, 18: 417-39.

Ranga, M., S. Temel, I.M. Ar, R.B. Yesilay, and F.V Sukan (2016). "Building technology transfer capacity in Turkish universities: A critical analysis." European Journal of Education, 51: 90-106.

Rosli, A. and F. Rossi (2014). Explaining the Gap between Policy Aspirations and Implementation: The Case of University Knowledge Transfer Policy in the United Kingdom. CIMR Research Working Paper Series, Working Paper No. 20, Birbeck, University of London.

Shen, Y.-C. (2016). Identifying the Key Barriers of University-Industry Linkage in Taiwan. Paper presented at ISPIM Innovation Forum, Boston, March 13-16, 2016.

Siegel, D.S., D. Waldman D., and A. Link (2003). "Assessing the impact of organizational practices on the relative productivity of university technology transfer offices: An exploratory study." Research Policy, 32: 27-48.

Walsh, J.P. (2016). "Openness and innovation in the US: Collaboration form, idea generation and implementation." Research Policy, 45: 1660-71.

Walter, T., C. Ihl, R. Mauer, and M. Brettel (2013). "Grace, gold, or glory? Exploring incentives for invention disclosure in the university context." Journal of Technology Transfer, 38: 1-35.

Weckowska, D.M. (2015). "Learning in university technology transfer offices: Transactions-focused and relations-focused approaches to commercialization of academic research." Technovation, 41-42: 62-74.

WIPO (2011). "Harnessing public research for innovation - the role of intellectual property." In World Intellectual Property Report 2011: The Changing Face of Innovation. Geneva: World Intellectual Property Organization (WIPO). www.wipo.int/edocs/pubdocs/en/wipo_pub_944_2011-chapter4.pdf.

Zhang, Q., N.G. MacKenzie, D. Jones-Evans, and R. Huggins (2016). "Leveraging knowledge as a competitive asset? The intensity, performance and structure of universities entrepreneurial knowledge activities at a regional level." Small Business Economics, 47: 657-75. 